\title{
A laparoszkópia szerepe a 80 évesnél idősebb betegek epekövességének megoldásában
}

\author{
Kakucs Tímea dr. - Harsányi László dr. \\ Kupcsulik Péter dr. - Lukovich Péter dr. \\ Semmelweis Egyetem, Általános Orvostudományi Kar, I. Sebészeti Klinika, Budapest
}

\begin{abstract}
Bevezetés: Az epehólyag-kövesség előfordulási gyakorisága az életkorral nő, azonban a 80 év feletti betegek mútétjeinek kimeneteléről alig vannak adatok. A társadalom elöregedésével a kérdés egyre időszerúbb. Célkitüzés: A 80 évesnél idősebb betegeknél végzett akut és elektív cholecystectomiák elemzése. Módszer: A szerzők az elmúlt hat évben a 80 évesnél idősebb, cholelithiasis miatt operált betegeknél a mütét típusát, a konverzió arányát, a szövődmények gyakoriságát, a posztoperatív mortalitást, az intenzív osztályos és kórházi ápolási napok számát vizsgálták retrospektíven. Eredmények: A vizsgált időszakban a 69 elektív, 51 akut mútétet végeztek, utóbbiak 9,8\%-ánál pancreatitist, 14\%-ánál májtályogot, 27\%-ánál choledocholithiasist találtak. Az elektív csoport 84\%-ánál, míg az akut csoport 17,7\%-ánál sikerült az epehólyag laparoszkópos eltávolítása. Az intenzív osztályos 9,1 vs. 1 nap, a teljes kórházi ápolás 12 vs. 3,6 nap volt az akut, illetve tervezett mütétnél. A sürgősséggel operált betegeknél a mortalitás $20 \%$ és a reoperáció $16 \%$ volt, elektív betegeknél egyik sem fordult elő. Következtetések: A laparoszkópos cholecystectomia idős betegek tervezett mútéteinél kiváló eredménnyel alkalmazható, ezért cholelithiasis esetén 80 év feletti betegeknél is törekedni kell az elektív mútétre. Orv. Hetil., 2016, 157(5), 185-190.
\end{abstract}

Kulcsszavak: cholecystectomia, laparoszkópia, idős, morbiditás, mortalitás

\section{The role of laparoscopy in cholecystectomy in patients with age of 80 or above}

Introduction: The incidence of cholelithiasis increases with age, however, there is still little data about the outcomes of cholecystectomy in patients with age of 80 and above. Population ageing presents tremenduous challenges for surgeons. Aim: The aim of the authors was to compare emergency and elective cholecystectomies performed in these elderly patients. Method: This retrospective study was based on the analysis of operation type, conversion rate, complications, mortality, length of hospital stay of all patients over 80 who underwent cholecystectomy in the last 6 years at the lst Department of Surgery, Semmelweis University. Results: 69 elective and 5lemergency operations were performed. In the emergency group pancreatitis was found in $9.8 \%$, liver abscess in $14 \%$, and common bile duct stones in $27 \%$ of the patients on admission. Laparoscopic cholecystectomy could be performed in $84 \%$ of patients in the elective group, while in $17.7 \%$ of patients in the emergency group. The length of stay at the intensive care unit was 9.1 and 1 days, while the total length of hospital stay was 12 and 3.6 days for the elective and emergency groups, respectively. In the emergency group mortality was $20 \%$ and reoperation was performed in $16 \%$ of patients, while at the elective group none of these occured. Conclusion: Laparoscopic cholecystectomy is safe as elective surgery for patients with age of 80 and above. For this reason the authors recommend elective cholecystectomy in this age group.

Keywords: cholecystectomy, laparoscopy, extreme elderly, morbidity, mortality

Kakucs, T., Harsányi, L., Kupcsulik, P., Lukovich, $P$. [The role of laparoscopy in cholecystectomy in patients with age of 80 and above]. Orv. Hetil., 2016, 157(5), 185-190.

(Beérkezett: 2015. november 24.; elfogadva: 2015. december 17.) 
Az Eurostat felmérése szerint 2014-ben az Európai Unió lakosságának 18,5\%-a 65 év feletti, míg 5,1\%-a 80 év feletti volt. Magyarországon az összlakosság 4,2\%-a haladta meg a 80 éves kort. Az elmúlt 15 évben a 80 év feletti populáció aránya jelentősen és folyamatosan emelkedik, 2001-ben még csak 3,5\%-ot tett ki ez a korosztály az Európai Unióban. A demográfiai előrejelzések azt mutatják, hogy az elöregedés tovább folytatódik, 2080-ra Magyarországon nyolcból egy fó 80 éven túli lesz, ez a lakosság 12,8\%-át jelenti majd.

$\mathrm{Az}$ életkor a sebészeti beavatkozások kockázatát fokozza, így a társadalom elöregedése a sebészeket is kihívás elé állítja. Az epehólyag-kövesség előfordulási gyakorisága az életkor előrehaladásával robbanásszerúen nő [1], a 70 év feletti korcsoportban a nők 50\%-ánál, a férfiak 16\%-ánál igazolható cholelithiasis [2, 3], ugyanakkor a 80 év feletti betegeknél epehólyag-kövesség miatt végzett mütétek kimeneteléről, kockázati tényezőikről, perioperatív morbiditási és mortalitási adataikról, a választandó mütéti típusról alig vannak adatok.

\section{Módszer}

A Semmelweis Egyetem, I. Sebészeti Klinikán 2009. január 1. és 2014. december 31. között epehólyag-kövesség miatt elektíven és sürgősen operált 80 év feletti betegek adatait dolgoztuk fel retrospektív módon. Vizsgáltuk a mütét technikáját (laparoszkópos vagy nyitott cholecystectomia), a konverzió arányát, a mütéti időt, a sebészi és nem sebészi szövődmények előfordulásának gyakoriságát, a posztoperatív mortalitást, a preoperatív acetilszalicilsav- (American Society of Anesthesiologists classification) pontok függvényében, illetve az intenzív osztályon, valamint a kórházban töltött napok számát. A vizsgálatból kizártuk azokat a cholecystectomiákat, ahol ennek elvégzésére nem elsődleges javallattal került sor, hanem egyéb mútét részét képezte (például pancreatoduodenectomia, májreszekció).

A statisztikai elemzéshez GraphPad Instat 3 (GraphPad Software, San Diego, Kalifornia) programot használtunk, ahol normalitásvizsgálathoz Kolmogorov-Smirnov-tesztet, szignifikanciavizsgálathoz Mann-Whitneyféle próbát, míg korrelációanalízishez Spearman-féle nem paraméteres vizsgálatot használtunk. Minden esetben az eredményeket $\mathrm{p}<0,05$ esetén tekintettük szignifikánsnak.

\section{Eredmények}

A vizsgált időszakban 80 évesnél idősebb beteget összesen 994 alkalommal operáltunk, ami az összes mútét körülbelül 5\%-át jelenti. A betegcsoport 59\%-a választottan, 41\%-a pedig sürgôsséggel került mütétre. A beavatkozás indikációja 120 betegnél volt epekövesség - akut mútét 51 esetben $(42,5 \%)$, elektív mútét 69 esetben $(57,5 \%)$.

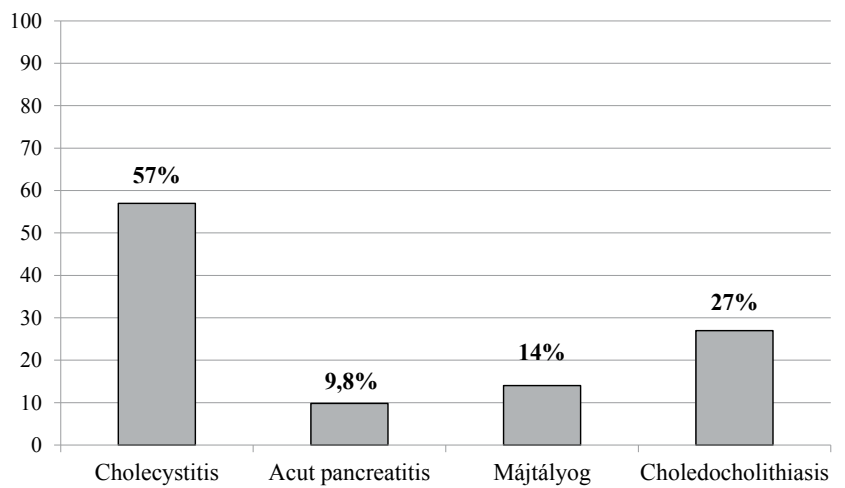

1. ábra $\mid$ A felvételkor észlelt szövődményes formák százalékos megoszlása az akut csoportban

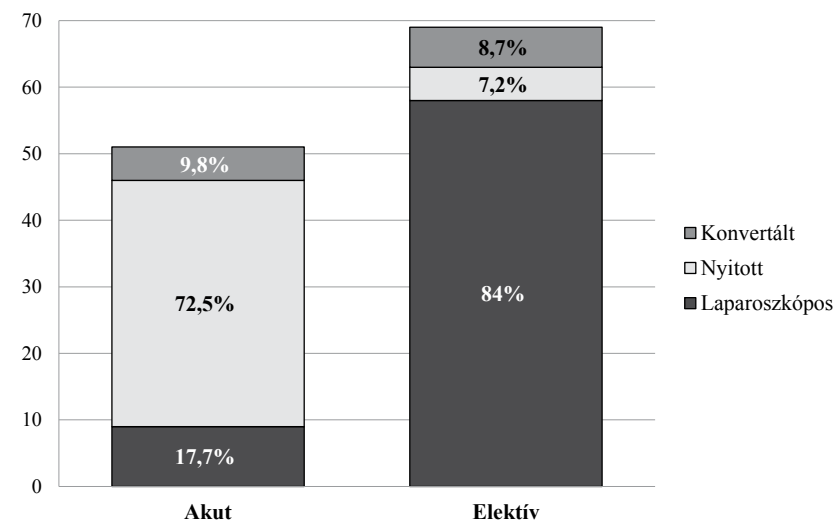

2. ábra $\quad$ A mútéti típusok százalékos megoszlása az akutan és elektíven operált betegek körében

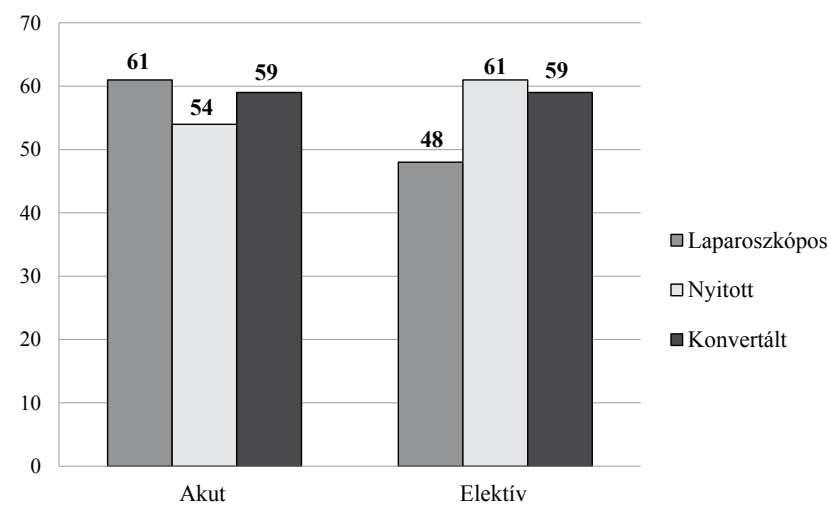

3. ábra $\quad$ A mútéti idők (perc) alakulása az akut és az elektív esetekben

A 80 év feletti választottan operált esetek 11,8\%-a, míg az akut mütétek $11,1 \%$-a volt cholecystectomia. A cholecystectomián átesett betegek átlagéletkora 84 év (elektív: 82 év, akut: 86 év), a férfi/nő arány 32\%/68\% volt.

Az elektíven mütétre kerülő betegek preoperatív ASApontszáma átlagosan 2,87, míg az akutan operált betegeké 3,4l volt, a különbség szignifikáns volt $(\mathrm{p}<0,0001)$. 
Az akutan felvett betegek mütét előtt 3,1 napot töltöttek a klinikán.

Az elektív csoportban 5 betegnél $(7,2 \%)$ hagyományos, nyitott cholecystectomiát, míg 58-nál (84\%) a laparoszkópos módszert választottuk. Hat esetben (8,7\%) laparoszkóposan kezdtük a műtétet, később konverzióra kényszerültünk (egy esetben intraoperatívan igazolt cholecystoduodenalis sipoly, a többi esetben súlyos összenövések és a Calot-háromszög képleteinek biztonságos kipreparálásának nehézsége miatt).

Az akutan operált betegek 57\%-ánál csak heveny epehólyag-gyulladást találtunk, azonban 9,8\%-uknál akut pancreatitis, 14\%-uknál májtályog, valamint 27\%-uknál choledocholithiasis is társult ehhez (1. ábra).

Az akut csoportnál mindössze 9 esetben $(17,7 \%)$ történt laparoszkóposan az epehólyag-eltávolítás, 5 betegnél $(9,8 \%)$ konverzióra volt szükség, 37 esetben $(72,5 \%)$ eredendően nyitott cholecystectomia történt (2. ábra).
Az átlagos mútéti idő az elektív csoportban 48 perc volt a laparoszkóposan, 61 perc a nyitottan operált betegeknél, míg 59 perc a konvertált mütéteknél. Az akutan operált betegek mütéti ideje a különböző módon operált betegeknél a következőképpen alakult: 61 perc a laparoszkópos, 54 perc a nyitott cholecystectomiában részesített betegeknél, valamint 59 perc a konvertált esetekben (3. ábra).

$\mathrm{Az}$ akutan operált betegek esetében a mútétig eltelt idő és a műtéti idő között nem találtunk korrelációt ( $\mathrm{r}=$ $0,0576, p=0,7308)$. Ehhez hasonlóan, nem találtunk korrelációt a mütétig eltelt idő és a laparoszkópos cholecystectomia mütéti ideje között sem $(\mathrm{r}=-0,0297, \mathrm{p}=$ $0,9484)$.

Az elektíven operált betegek mindössze 6\%-a (4 beteg) igényelt a posztoperatív időszakban intenzív terápiás ellátást, és ezeknél a betegeknél az intenzív osztályon töltött napok száma csupán 1 nap volt, bennfekvésük

1. táblázat | A meghalt betegek adatai (a halál kórbonctani oka nem volt megadható, mivel minden esetben a családok kérték a boncolás mellőzését)

\begin{tabular}{|c|c|c|c|c|c|c|c|c|c|c|c|}
\hline & Nem & $\begin{array}{l}\text { Élet- } \\
\text { kor } \\
\text { (év) }\end{array}$ & Felvételi státusz & $\begin{array}{l}\text { Mütétig } \\
\text { eltelt idő } \\
\text { (nap) }\end{array}$ & ASA & Mútét neme & $\begin{array}{l}\text { Mütét } \\
\text { ideje } \\
\text { (perc) }\end{array}$ & $\begin{array}{l}\text { Reoperá- } \\
\text { ció }\end{array}$ & $\begin{array}{l}\text { ITO- } \\
\text { napok } \\
\text { száma }\end{array}$ & $\begin{array}{l}\text { Kórházi } \\
\text { napok } \\
\text { száma }\end{array}$ & Klinikai halálok \\
\hline 1. & Férfi & 89 & $\begin{array}{l}\text { Cholecystitis ac. } \\
\text { gangr., abscessus } \\
\text { hepatis }\end{array}$ & 0 & 4 & $\begin{array}{l}\text { Nyitott } \\
\text { cholecystectomia, } \\
\text { oncotomia hepatis }\end{array}$ & 90 & $\begin{array}{l}2 \\
\text { alkalom- } \\
\text { mal }\end{array}$ & 20 & 20 & $\begin{array}{l}\text { Septicaemia, insuf. } \\
\text { cardiaca ac. }\end{array}$ \\
\hline 2. & Nö & 92 & Pancreatitis ac. necrot. & 8 & 5 & $\begin{array}{l}\text { Nyitott } \\
\text { cholecystectomia, } \\
\text { necrectomia et } \\
\text { oncotomia pancreatis }\end{array}$ & 55 & $\begin{array}{l}1 \\
\text { alkalom- } \\
\text { mal }\end{array}$ & 32 & 37 & $\begin{array}{l}\text { Pancreatitis ac., } \\
\text { septicaemia, MOF }\end{array}$ \\
\hline 3. & Férfi & 85 & $\begin{array}{l}\text { Cholecystitis et } \\
\text { pancreatitis ac. }\end{array}$ & 14 & 4 & $\begin{array}{l}\text { Nyitott } \\
\text { cholecystectomia }\end{array}$ & 74 & $\begin{array}{l}1 \\
\text { alkalom- } \\
\text { mal }\end{array}$ & 45 & 46 & $\begin{array}{l}\text { Pancreatitis ac., } \\
\text { septicaemia, MOF }\end{array}$ \\
\hline 4. & Nő & 88 & Cholecystitis ac. gangr. & 0 & 4 & $\begin{array}{l}\text { Nyitott } \\
\text { cholecystectomia }\end{array}$ & 85 & $\begin{array}{l}\text { Nem } \\
\text { történt }\end{array}$ & 2 & 2 & Septicaemia, MOF \\
\hline 5. & Nő & 85 & $\begin{array}{l}\text { Abscessus hepatis, } \\
\text { choledocholithiasis, } \\
\text { cholangitis ac. }\end{array}$ & 1 & 4 & $\begin{array}{l}\text { Oncotomia hepatis, } \\
\text { choledochotomia et } \\
\text { Kehr-drainage }\end{array}$ & 30 & $\begin{array}{l}1 \\
\text { alkalom- } \\
\text { mal }\end{array}$ & 52 & 53 & $\begin{array}{l}\text { Septicaemia, insuf. } \\
\text { cardiaca ac. }\end{array}$ \\
\hline 6. & Nô & 96 & $\begin{array}{l}\text { Choledocholithiasis, } \\
\text { icterus mechanicus, } \\
\text { cholangitis ac. }\end{array}$ & 0 & 5 & $\begin{array}{l}\text { Nyitott } \\
\text { cholecystectomia, } \\
\text { choledochotomia, } \\
\text { duodenotomia, } \\
\text { kőextractio, intraop. } \\
\text { cholangiographia, } \\
\text { Kehr-drainage }\end{array}$ & 75 & $\begin{array}{l}\text { Nem } \\
\text { történt }\end{array}$ & 0 & 0 & Insuf. cardiaca ac. \\
\hline & Nő & 90 & Cholecystitis ac. & 10 & 4 & $\begin{array}{l}\text { Nyitott } \\
\text { cholecystectomia }\end{array}$ & 57 & $\begin{array}{l}\text { Nem } \\
\text { történt }\end{array}$ & 5 & 23 & $\begin{array}{l}\text { Pneumonia l. u., } \\
\text { septicaemia, MOF }\end{array}$ \\
\hline 8. & Nő & 84 & $\begin{array}{l}\text { Cholecystitis ac. } \\
\text { gangr., pancreatitis ac. }\end{array}$ & 0 & 4 & $\begin{array}{l}\text { Nyitott } \\
\text { cholecystectomia, } \\
\text { necrectomia pancreatis, } \\
\text { Cysticus drain }\end{array}$ & 82 & $\begin{array}{l}\text { Nem } \\
\text { történt }\end{array}$ & 8 & 8 & $\begin{array}{l}\text { Pancreatitis ac., } \\
\text { septicaemia, MOF }\end{array}$ \\
\hline 9. & Férfi & 84 & Pancreatitis ac. necrot. & 0 & 4 & $\begin{array}{l}\text { Necrectomia et } \\
\text { oncotomia pancreatis, } \\
\text { Cholecystectomia }\end{array}$ & 62 & $\begin{array}{l}\text { Nem } \\
\text { történt }\end{array}$ & 33 & 33 & $\begin{array}{l}\text { Pancreatitis ac., } \\
\text { septicaemia, MOF }\end{array}$ \\
\hline 10. & Nő & 87 & $\begin{array}{l}\text { Cholecystitis ac. } \\
\text { gangr., abscessus } \\
\text { hepatis }\end{array}$ & 0 & 4 & $\begin{array}{l}\text { Nyitott } \\
\text { cholecystectomia }\end{array}$ & 55 & $\begin{array}{l}1 \\
\text { alkalom- } \\
\text { mal }\end{array}$ & 3 & 33 & Septicaemia, MOF \\
\hline
\end{tabular}

$\mathrm{MOF}=($ multiorgan failure) többszervi elégtelenség. 
alatt mortalitást nem észleltünk. Ugyanakkor a sürgősen mütétre került betegek 61\%-a került a mütétet követően intenzív osztályra, ahol utána átlagosan 9,1 napot töltöttek (4. ábra). A posztoperatív mortalitás ebben a csoportban 20\% (10 beteg) volt. Az elhalálozott betegek átlagéletkora 88 év volt. A 10 meghalt betegből 4-nél akut pancreatitist, 2-nél májtályogot, egynél közös epeútkövet, míg egy másik betegnél májtályogot és közös epeútkövet észleltünk felvételkor. Az elhunyt betegek felvételi ASA-értéke szignifikánsan rosszabb volt, mint a túlélő csoporté (elhunyt vs. életben maradt: 4,2 vs. 3,25, $\mathrm{p}<0,001$ ) (1. táblázat).

Megvizsgáltuk a preoperatív ASA-pontszám és az intenzív osztályon töltött napok számát, és nem találtunk korrelációt a kettő között $(\mathrm{r}=-0,0416, \mathrm{p}=0,7226)$.

A posztoperatív időszakban az elektíven operált betegek 4,4\%-ánál (3 betegnél) észleltünk minor szövődményt (enyhe odaemás pancreatitis, amely konzervatív kezelésre gyógyult, illetve átmeneti lázas állapotot, amely spontán megszűnt), reoperációra egyetlen betegnél sem volt szükség. Ezzel szemben az akutan végzett beavatkozás után 16\%-ban történt reoperáció, s a tíz, halálhoz vezető szövődmény mellett 29\%-ban minor sebészi szövődmény (sebgennyedés, posztoperatív choledocholithiasis, amely miatt ERCP történt, subhepaticus tályog, amelyet CT-vezérelve drenáltunk) alakult ki. Emellett további 12\%-ban nem sebészi szövődményt (tüdőgyulladás, kardiális történés, Clostridium difficile-infekció) kellett kezelnünk (2. táblázat).

Az ASA-pontszám és a posztoperatív kórházban töltött napok száma között gyenge korrelációt találtunk, a különbség szignifikáns volt $(\mathrm{r}=0,3399, \mathrm{p}=0,0029)$. A mútétig eltelt idő és a posztoperatív napok száma között nem volt korreláció $(\mathrm{r}=-0,2408, \mathrm{p}=0,1293)$.

A végleges szövettani leletek szerint az akutan operált betegek $8,2 \%$-ánál - preoperatívan fel nem ismert - malignus folyamat állt a háttérben $(3$ esetben adenocarcinoma, 1 esetben laphámcarcinoma). Az elektíven operált csoportban egy esetben $(1,5 \%)$ fordult elö malignus folyamat (adenocarcinoma).

Míg a választottan operált betegek átlagosan 3,6 napot töltöttek mütét után klinikánkon, és minden beteg otthonába távozott, addig a sürgős mütétek után az ápolási idő 12 nap volt, amelyet követően $62 \%$-uk otthonába távozott, 18\%-ukat további kezelés céljából más intézménybe helyeztünk át (4., 5. ábra).

2. táblázat | Posztoperatív szövődmények előfordulási gyakorisága

\begin{tabular}{lll}
\hline & Elektív & Akut \\
\hline Szövődménymentes & $95,7 \%$ & $35 \%$ \\
Minor sebészi szövődmény & $4,4 \%$ & $29 \%$ \\
Nem sebészi szövődmény & $0 \%$ & $12 \%$ \\
Major sebészi szövődmény (reoperáció) & $0 \%$ & $16 \%$ \\
Meghalt & $0 \%$ & $20 \%$ \\
\hline
\end{tabular}

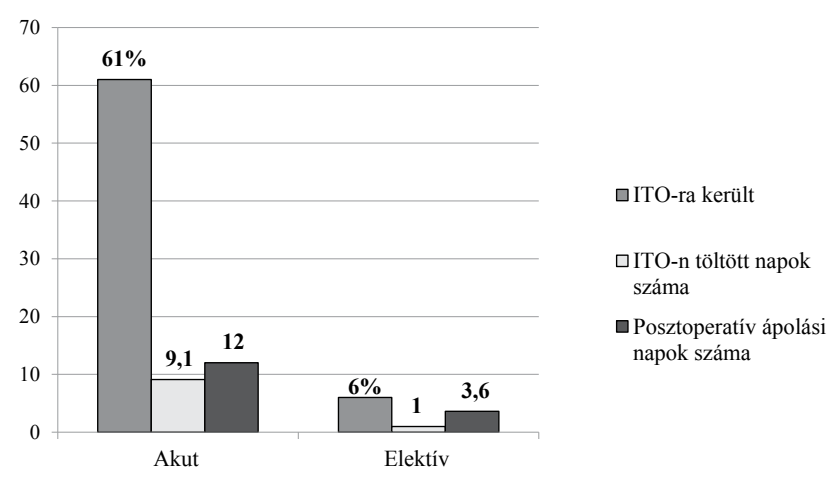

4. ábra $\quad$ Az intenzív osztályos ellátást igénylő betegek százalékos meg oszlása, az intenzív osztályon töltött, illetve a posztoperatív ápolási napok száma

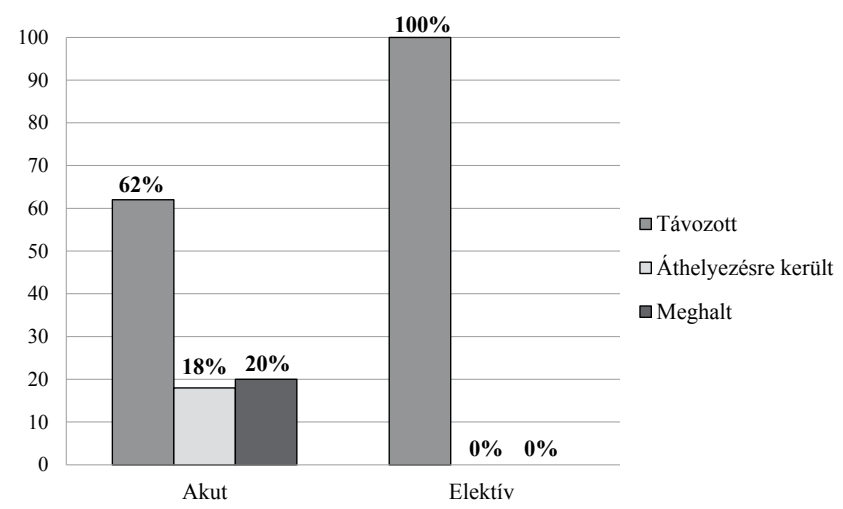

5. ábra | A mütét kimenetele

\section{Megbeszélés}

A szakirodalomban nem létezik pontos definíció arra vonatkozóan, hogy hány éves kortól beszélhetünk időskorról. A WHO meghatározása szerint 65 év felett „idősebbekről”, míg 80 éves kortól „legidősebbekről” beszélünk. Az időskorúak sebészi betegségeiről közölt cikkek nagy része 65-70 év feletti betegek adatait dolgozza fel, holott a társadalmak öregedésével a 80 évesnél idősebb populáció már jelentős betegcsoportot képvisel $[4,5]$.

Napjainkban az egyik leggyakoribb sebészeti beavatkozást igénylő betegség az epehólyag-kövesség, amelynek „gold standard” mútéti megoldása a laparoszkópos cholecystectomia. Erich Mühe 1985. szeptember 12-én végezte az első laparoszkópos cholecystectomiát, és 1986 áprilisában a Német Sebész Táraság kongresszusán már lényegében ismertette a módszer összes előnyét [6]. A technika okozta kezdeti nehézségeket legyőzve, speciális oktatási módszerek kerültek kidolgozásra [7], és az eltelt 30 év alatt nemcsak a szövődmények száma, hanem a mútéti idő is felére csökkent [8]. Többek között ennek köszönhető, hogy választott betegcsoportban a világon - de gyakran hazánkban is - egynapos sebészet kereté- 
ben, sôt akár ambuláns mútétként is végzik a laparoszkópos cholecystectomiát [9].

A javuló laparoszkópos eredmények ellenére nem történt szemléletváltozás az epehólyag-kövesség kezelésében: a belgyógyászok jelentős része napjainkban is csak panaszok esetén javasolja a sebészeti kezelést. Sőt idős betegek esetében még panaszokat okozó cholelithiasis esetén is - elsősorban a beteg kora, továbbá a gyakori súlyos társbetegségek miatt - gyakran ellenzik a mútéti megoldást.

Számos tanulmány számol be arról, hogy az időskorban előforduló epehólyag-kövesség gyakrabban okoz heveny epehólyag-gyulladást, alakul ki biliaris pancreatitiszszel, choledocholithiasissal járó szövődményes forma, mint fiatalkorban $[10,11]$. Ezt igazolja anyagunk is, hiszen a 10 meghalt beteg közül 9-et már súlyos szövődménnyel vettünk fel.

Heveny epehólyag-gyulladást okozó epehólyag-kövesség esetén a sebészeti ellátás egyik fontos kérdése a mütét időzítése, ugyanis a sikeres laparoszkópos mütét esélye jelentősen csökken a panaszok kezdetétől számított 48 órán túl. Ez a tény a belgyógyászok körében, sajnos, nem közismert, így a betegek egy része már későn - többnapos konzervatív kezelés után - kerül a sebészek látókörébe. Pedig Kuwabara 2552, 60 év feletti betegnél akiknek 15\%-a 80 év feletti volt - elvégzett elektív és akut cholecystectomia adatait feldolgozva egyértelmúen igazolta, hogy a 48 órán túl elvégzett cholecystectomiák esetében szignifikánsan hosszabb volt a mútéti idő, valamint a posztoperatív kórházi tartózkodási napok száma [12]. Be kell vallanunk, hogy idős betegek esetében olykor mi, sebészek is könnyebben döntünk a konzervatív kezelés mellett, s a betegek 30\%-a még intervenciós terápiában (ERCP, EST) sem részesül $[13,14]$. Pedig a korai cholecystectomia előnyös az időskorúak enyhe biliaris pancreatitisének kezelésében is [15].

Míg a laparoszkópos technika elterjedésekor még számos olyan relatív ellenjavallata volt a módszernek, amely az idős betegeknél gyakrabban fordul elő (például korábbi kardiális történés, légzőszervi megbetegedések, illetve maga az időskor), mára egyértelmúvé vált, hogy ez a betegcsoport is nyer a laparoszkópos technika alkalmazásával - elsősorban a posztoperatív szakban. Ezek a betegek gyorsabban mobilizálhatók, így csökken a pneumonia, mélyvénás trombózis esélye is. Így ennél a betegcsoportnál a mütéti késlekedés esetén a szövődmények esélye hatványozottan nő.

A késlekedés is magyarázata lehet annak, hogy a preoperatív ASA-pontszám szignifikánsan nagyobb volt az elhalálozott betegeinknél, mint az életben maradt csoportnál - ugyanakkor vélhetóleg a betegek rossz általános állapota miatt döntöttünk konzervatív kezelés mellett. Az akutan és az elektíven operált betegek ASApontjai között is szignifikáns volt a különbség.
Egyértelmű, hogy akut tünetek esetén a késlekedés fatális következményekkel járhat. Elektív cholecystectomiát javasolni - föleg egy esetlegesen panaszmentes betegnek - ugyanakkor nagy felelősség. A Dán Cholecystectomia Adatbázis 2006-2010 közötti mütéteinek adatai alapján a szerzők arra a következtetésre jutottak, hogy bár az életkor a kórházi tartózkodási napok számának, valamint a posztoperatív morbiditás és mortalitás gyakoriságának független rizikófaktora, ismert epehólyag-kövességet elektíven, még heveny epehólyag-gyulladás létrejötte előtt meg kell operálni [16]. A mi eredményeink is azt támasztják alá, hogy az akut, szövődményes cholecystolithiasis esetében $20 \%$-os posztoperatív mortalitás volt megfigyelhető az elektíven operált betegek 0\%os mortalitásával szemben. $S$ bár az életkor előrehaladásával a konverzió esélye nő, ez nem közvetlenül az életkorral van összefüggésben, hanem szintén azzal, hogy az akut cholecystitis gyakoribb ebben a populációban [16].

Akutan végzett mütétek esetén a mütétet végző team kiválasztására korlátozottak a lehetőségek. Az ilyen nagy kockázattal járó mütéteknél nemcsak az operatőr, hanem az asszisztens megválasztása is fontos [17]. A megfelelő gyakorlat ugyanis nemcsak a gyorsan elvégezhető mütét és emiatt rövidebb narkózis miatt fontos, hanem a konverzió időpontjának eldöntésében is nagy jelentőséggel bír.

\section{Következtetések}

Elmondható, hogy napjainkra a laparoszkópos technika alkalmazásával az elektív cholecystectomia kockázata kisebb, mint az epekövesség okozta szövődményekben végzett mútét morbiditása és mortalitása. Ezért tünetmentes epekövek esetében is indokoltnak tartjuk a cholecystectomia elvégzését. A 80 év feletti életkor egymagában nem ellenjavallata a laparoszkópos mútétnek, ezeknél a betegeknél is törekedni kell a választott időpontban történő ellátásra, mivel a szövődményes eset igen magas morbiditási és mortalitási eséllyel jár. Akut cholecystitis esetén nagy gyakorlattal rendelkező teammel korai mütét javasolt.

Anyagi támogatás: A közlemény megírása, illetve a kapcsolódó kutatómunka anyagi támogatásban nem részesült.

Szerzői munkamegosztás: K. T.: Adatgyưjtés, statisztikai elemzés, a kézirat megszövegezése, irodalomkutatás. H. L., K. P.: A kézirat javítása. L. P.: A hipotézisek kidolgozása, a kézirat javítása, irodalomkutatás. A cikk végleges változatát valamennyi szerző elolvasta és jóváhagyta.

Érdekeltségek: A szerzőknek nincsenek érdekeltségeik. 


\section{Irodalom}

[1] Rispoli, C., Rocco, N., Ianonne, L., et al.: Developing guidelines in geriatric surgery: role of the grade system. BMC Geriatrics, 2009, 9(Suppl. 1), A98

[2] Bingener, J., Richards, M. L., Schwesinger, W. H., et al.: Laparoscopic cholecystectomy for elderly patients: gold standard for golden years? Arch. Surg., 2003, 138(5), 531-535.

[3] Hazzan, D., Geron, N., Golijanin, D., et al.: Laparoscopic cholecystectomy in octogenarians. Surg. Endosc., 2003, 17(5), 773776 .

[4] Agrusa, A., Romano, G., Frazetta, G., et al.: Role and outcomes of laparoscopic cholecystectomy in the elderly. Int. J. Surg., 2014, 12(Suppl. 2), S37-S39

[5] Loureiro, E. R., Klein, S. C., Pavan, C. C., et al.: Laparoscopic cholecystectomy in 960 elderly patients. Rev. Col. Bras. Cir., $2011,38(3), 155-160$

[6] Litynski, G. S.: Erich Mühe and the rejection of laparoscopic cholecystectomy (1985): a surgeon ahead of his time. JSLS, 1998, 2(4), 341-346.

[7] Kakucs, T., Lukovich, P., Dobó, N., et al.: Measuring residents' and specialists' laparoscopic technique with the MENTOR ${ }^{\circledR}$ training box. [Rezidensek és szakorvosok laparoscopos technikájának felmérése $\mathrm{MENTOR}^{\circledR}$ tréningboksz segítségével.] Magy. Seb., 2013, 66(2), 55-61. [Hungarian]

[8] Lukovich, P., Vanca, T., Gero, D., et al.: The development of laparoscopic technology in light of cholecystectomies performed between 1994 and 2007. [A laparoszkópos cholecystectomia fejlődése az 1994-ben és 2007-ben végzett cholecystectomiák tükrében.] Orv. Hetil., 2009, 150(48), 2189-2193. [Hungarian]

[9] Al-Omani, S., Almodhaiberi, H., Ali, B., et al.: Feasibility and safety of day-surgery laparoscopic cholecystectomy: a single-in- stitution 5-year experience of 1140 cases. Korean J. Hepatobiliary Pancreat. Surg., 2015, 19(3), 109-112.

[10] Pavlidis, T. E., Marakis, G. N., Symeonidis, N., et al.: Considerations concerning laparoscopic cholecystectomy in the extremely elderly. J. Laparoendosc. Adv. Surg. Tech. A, 2008, 18(1), 5660 .

[11] Brunt, L. M., Quasebarth, M. A., Dunnegan, D. L., et al.: Outcomes analysis of laparoscopic cholecystectomy in the extremely elderly. Surg. Endosc., 2001, 15(7), 700-705

[12] Kuwabara, K., Matsuda, S., Fushimi, K., et al.: Relationships of age, cholecystectomy approach and timing with the surgical and functional outcomes of elderly patients with cholecystitis. Int. J. Surg., 2011, 9(5), 392-399.

[13] Arthur, J. D., Edwards, P. R., Chagla, L. S.: Management of gallstone disease in the elderly. Ann. R. Coll. Surg. Engl., 2003, 85(2), 91-96.

[14] Siegel, J. H., Kasmin, F. E.: Biliary tract diseases in the elderly: management and outcomes. Gut, 1997, 41(4), 433-435.

[15] Trust, M. D., Sheffield, K. M., Boyd, C. A., et al.: Gallstone pan creatitis in older patients: Are we operating enough? Surgery, $2011,150(3), 515-525$.

[16] Nielsen, L. B., Harboe, K. M., Bardram, L.: Cholecystectomy for the elderly: no hesitation for otherwise healthy patients. Surg. Endosc., 2014, 28(1), 171-177.

[17] Lukovich, P., Zsirka, A., Harsányi, L.: Changes in the operating time of laparoscopic cholecystectomy of the surgeons and novices between 1994-2012. Chirurgia (Bucur.), 2014, 109(5), 639-643.

\section{Eladó praxis}

Tiszaföldváron családi okból 1700 fős jól karbantartott felnőtt háziorvosi praxis eladó. Nagyon jó beteganyag, kiváló asszisztencia, segitőkész kollégák.

A rendelö önkormányzati tulajdonú, felújitott. A városban központi ügyelet van, részvétel nem kötelező.

Szükség esetén igényes lakás a rendelö közelében.

Dr. Kis Gábor (+3630-9381-046) gabrius@freemail.hu

\section{Eladó praxis Németországban}

\section{Bajorországban az osztrák határtól egy kilométerre 40 éve müködő praxishely} a város központi részében átadó komplett felszereléssel.

(Computerek, ultrahang, doppler ergotherapia, stb.) Az átadáshoz jogi segítségre is van lehetőség.

$$
\begin{aligned}
& \text { Érdeklődés: Magyarországon: +3630/5263-209 } \\
& \text { Németországban: } 0049 \text { 8679171555 }
\end{aligned}
$$

